\title{
Pengembangan E-Modul Berbasis Inkuiri Terbimbing Terintegrasi Multirepresentasi dan Virtual Laboratory pada Materi Larutan Elektrolit dan Nonelektrolit untuk Kelas X SMA/MA
}

\author{
Annisatul Aulia ${ }^{1}$ and Andromeda ${ }^{1 *}$ \\ ${ }^{1}$ Pendidikan Kimia, Universitas Negeri Padang, Jl. Prof. Dr. Hamka Air Tawar Barat, \\ Padang Utara, Sumatera Barat 25171, Indonesia \\ *andromedasaidir@yahoo.com
}

\begin{abstract}
Electrolyte and non-electrolyte solutions are materials consisting of theory and practicum so that teaching materials are needed that can support the characteristics of this material. The purpose of this study is to produce teaching materials in the form of integrated multi-representation and virtual laboratory based e-modules based on electrolyte and nonelectrolyte solution material, and reveal the validity and practicality of the modules produced. This type of research is Research and Development (R \& D) and uses a 4-D model which includes four stages, including the define, design, develop, and disseminate stages (at this stage not done). The validity test was carried out by three chemistry lecturers at FMIPA UNP and two chemistry teachers at SMAN 4 Pariaman using an instrument in the form of a validity questionnaire. Practical tests were carried out by three high school chemistry teachers and 25 students of class X IPA 1 in SMAN 4 Pariaman using an instrument in the form of a practical questionnaire. The average kappa moment $(\mathrm{k})$ the results of the validity and practicality tests by the teacher and students of e-modules are $0.90 ; 0.98 ; 0.83$ with a very high validity category, the practicality category of teachers is very high, and the practicality category of students is very high. The data shows that integrated guided inquiry-based e-modules are multi-representation and virtual laboratory on electrolyte and non-electrolyte solution material are valid and practical.
\end{abstract}

\section{Pendahuluan}

Larutan elektrolit dan nonelektrolit merupakan materi yang dipelajari pada kelas X semester genap. Elektrolit merupakan suatu zat apabila dilarutkan dalam air akan menghasilkan larutan yang dapat menghantarkan listrik, sedangkan nonelektrolit merupakan suatu zat yang apabila dilarutkan dalam air akan menghasilkan larutan yang tidak dapat menghantarkan listrik [1]. Berdasarkan silabus mata pelajaran kimia kurikulum 2013, menetapkan Kompetensi Dasar (KD) pada materi larutan elektrolit dan nonelektrolit yaitu 3.8 Menganalisis sifat larutan berdasarkan daya hantar listriknya, dan 4.8 Membedakan daya hantar listrik berbagai larutan melalui perancangan dan pelaksanaan percobaan.

Larutan elektrolit dan nonelektrolit memuat dimensi pengetahuan faktual, konsep, prinsip dan prosedural. Dalam belajar ilmu kimia siswa tidak hanya dituntut untuk mempelajari konsep-konsep dan prinsip sains secara verbalistis, hafalan, pengenalan rumus-rumus dan istilah-istilah melalui latihan secara verbal namun juga dituntut untuk memiliki pengalaman langsung melalui proses eksperimen agar terwujudnya pembelajaran yang menekankan pada keterampilan proses sains [2]. Keterampilan proses sains merupakan pengembangan keterampilan-keterampilan intelektual, sosial dan fisik yang bersumber dari dalam diri siswa [3]. Keterampilan proses sains juga menuntut siswa untuk terlibat secara langsung dalam pembelajaran sehingga siswa dapat menemukan sendiri fakta atau konsep yang nantinya akan lama teringat oleh siswa [4]. Keterampilan proses sains akan terlihat melalui Eksperimen.

Eksperimen dalam pembelajaran kimia sangat dibutuhkan, karena dengan eksperimen tersebut siswa 
dapat membuktikan teori yang telah dipelajarinya dan menemukan konsep dari eksperimen tersebut. Selain itu, kegiatan eksperimen dapat menumbuhkan minat dan motivasi siswa dalam belajar [5]. Kegiatan eksperimen tidak seluruh sekolah yang melakukan, dikarenakan minimnya fasilitas labor, seperti tidak tersedianya alat-alat dan bahan-bahan yang diperlukan, tidak adanya ruang laboratorium, serta waktu dalam pelaksanaanya. Salah satu cara yang dapat digunakan untuk mengatasi keterbatasan alat dan zat untuk praktikum adalah dengan menggunakan virtual laboratory. Virtual laboratory adalah lingkuangan yang interaktif untuk menciptakan dan melakukan eksperimen simulasi.Virtual laboratory bervariasi dari halaman web statis dengan vidio praktikum dan teks hingga ke halaman yang dinamis dengan lingkungan canggih, kolaboratif authoring [6]. Sehingga siswa dapat belajar secara aktif tanpa bantuan instruktur ataupun asisten dalam menggunakannya.

Sesuai dengan tujuan pembelajaran kurikulum 2013, bahwa pembelajaran dilaksanakan dengan menggunakan pendekatan saintifik. Pendekatan saintifik merupakan pendekatan pembelajaran yang berpusat pada siswa [7]. Untuk meningkatkan keaktifan siswa dalam proses pembelajaran tidak hanya ditentukan oleh tenaga pengajar yang baik atau kurikulum yang mantap, tetapi ditentukan oleh model pembelajaran yang digunakan guru [8]. Salah satu model pembelajaran kimia yang cocok adalah model pembelajaran inkuiri. Model pembelajaran inkuiri adalah suatu strategi belajar yang melibatkan secara maksimal seluruh kemampuan siswa untuk mencari dan menyelidiki secara sistematis, kritis, logis, dan analitis sehingga mereka dapat merumuskan sendiri penemuannya dengan penuh percaya diri [9]. Berdasarkan tingkat keterbukaannya inkuiri dibagi atas 4 yaitu inkuiri konfirmasi, inkuiri terstruktur, inkuiri terbimbing, inkuiri terbuka. Dari ke 4 jenis inkuiri tersebut inkuiri terbimbing lah yang relevan dengan psikologi siswa sekolah dasar dan menengah, karena dalam proses inkuiri ini masih mendapatkan bimbingan dari guru dalam melaksanakan tahapan inkuiri [10]. Tahapan inkuiri terbimbing meliputi: orientasi, eksplorasi, pembentukan konsep, aplikasi dan penutup.

Dalam menerapkan model pembelajaran kimia dibutuhkan bahan ajar yang dapat meningkatkan pemahaman siswa terhadap materi kimia. Salah satu bahan ajar yang banyak digunakan adalah modul. Modul merupakan salah satu bahan media cetak yang dirancang untuk dipelajari secara mandiri oleh siswa dalam pembelajaran, dimana dalam modul telah dilengkapi petunjuk untuk belajar mandiri [11]. Pada tahun 2018 telah dikembangkan sebuah modul cetak, oleh Deprina Yeni dengan judul pengembangan modul larutan elektrolit dan nonelektrolit berbasis inkuiri terbimbing terintegrasi eksperimen dan keterampilan proses sains. Bahan ajar modul tersebut sudah valid dan praktis digunakan. Bahan ajar modul memiliki beberapa kelemahan yaitu siswa cendrung bersifat informatif, gambar yang disajikan sederhana dan berisikan soal-soal latihan saja [12].

Materi larutan elektrolit dan nonelektrolit terdiri dari 3 aspek yang harus di pelajari oleh siswa yaitu makroskopis, submiskroskopis dan simbolik yang disebut juga dengan multirepresentasi. Untuk mempelajari aspek makroskopis dan simbolik dari materi tersebut akan terbantu dengan menggunakan modul. Sedangkan untuk mempelajari submikroskopis dari materi tersebut tidak bisa dengan menggunakan modul saja, karena dalam aspek submikroskopis ini memperlihatkan bagaimana suatu molekul dalam larutan dapat menghantarkan listrik dan tidak menghantarkan listrik. Bahan ajar modul tidak dapat menampilkan langsung animasi/ vidio bagaimana suatu larutan dapat menghantarkan listrik dan bagaimana suatu larutan tidak dapat menghantarkan listrik. Walaupun bisa tetapi harus membutuhkan alat bantu dulu seperti pengeras suara/ biaya audio-visual. Karena hal tersebut bahan ajar modul cetak akan memakan biaya lebih banyak [ 13]. Berdasarkan hasil wawancara guru kimia dan angket siswa di SMAN 2 Pariaman, SMAN 4 Pariaman dan MAN Kota Pariaman, ditemukan permasalahan bahwa 1) materi larutan elektrolit dan nonelektrolit merupakan materi sulit, ini di karenakan bahan ajar yang digunakan masih belum melibatkan siswa secara aktif dalam pembelajaran 2) Bahan ajar yang disajikan guru tidak menarik, karena siswa lebih tertarik jika bahan ajar yang digunakan berupa vidio, animasi dan gambar, 3) Pada materi larutan elektrolit dan nonelektrolit tidak dilaksanakan eksperimen (praktikum), karena alat yang digunakan untuk praktikum rusak serta laboratorium bergabung dengan kelas belajar. Kegiatan praktikum sangat penting karena siswa dapat menemukan kebenaran konsep dari eksperimen langsung [14].

Untuk mengatasi permasalahan tersebut guru dan siswa membutuhkan bahan ajar yang menarik untuk membuat siswa belajar mandiri serta dapat mengatasi keterbatasan fasilitas yang dimiliki sekolah seperti laboratorium. Seiring perkembangan zaman bahan ajar yang sesuai adalah bahan ajar 
elektronik. Dimana hampir semua siswa sudah bisa menggunakan komputer. Ditambah juga sekolah sudah memfasilitasi labor komputer beserta komputernya dalam menunjang proses belajar mengajar. Oleh karena masalah tersebut penulis ingin membuat bahan ajar berupa E-modul yang sesuai dengan perkembangan zaman dan teknologi. E-modul adalah bahan ajar modul berbasis teknologi informasi yang bersifat interaktif memudahkan dalam penyelidikan, menampilkan gambar, audio, vidio, animasi dan dilengkapi tes evalusai sebagai umpan balik dari pembelajaran. E-modul disajikan dalam format buku secara elektronik dengan menggunakan hard disk, disket, CD atau Flasdisk dan dapat dibaca dengan mengunakan komputer atau alat pembaca elektronik [15].

E-modul mempunyai keungulan diantaranya: e-modul dapat meningkatkan efektifitas dan fleksibilitas, pembelajaran dapat dilakukan kapan saja dan dimana saja, tidak terikat ruang dan waktu [16], Dapat meningkatkan motivasi peserta didik, dapat menyajikan lebih interaktif dan lebih dinamis dibandingkan dengan media cetak, menyajikan unsur visual dengan penggunaan vidio tutorial [17].

Bahan ajar e-modul dapat menampilkan vidio praktikum yang akan mengatasi akan keterbatasan laboratorium yang dimiliki serta menampilkan animasi dalam menambah wawasan terhadap materi yang sedang dipelajari. Ini sesui dengan implementasi kurikulum 2013 yang mencanagkan pendidikan abad 21. Pendidikan abad 21 merupakan pendidikaan yang mengintegrasikan antara pengetahuan, keterampilan dan sikap dengan penguasaan terhadap TIK [17].

Penelitian sebelumnya telah dihasilkan bahan ajar berupa Lembar Kerja Siswa (LKS) eksperimen berbasis inkuiri terbimbing pada materi laju reaksi telah efektif digunakan pada pembelajaran kimia dan dapat meningkatkan hasil belajar siswa [18]. Penelitian lainnya telah dihasilkan bahan ajar modul berbasis guided discovery learning yang telah efektif dan dapat meningkatkan kemampuan berpikir kritis siswa dan hasil belajar siswa SMA [19]. Penelitian lainnya dihasilkan bahan ajar modul berbasis inkuiri terbimbing terintegrasi eksperimen dan keterampilan proses sains pada materi kesetimbangan kimia yang efektif digunakan dalam proses pembelajaran dan dapat meningkatkan hasil belajar serta keterampilan proses sains siswa [4]. Penelitian lainnya mengenai modul elektronik animasi interaktif dapat disimpulkan bahwa kualitas modul elektronik animasi interaktif yang dikembagkan memenuhi kritia baik dan valid dari aspek materi, bahasa indonesia, dan media [12].

Berdasarkan pada permasalahan yang telah dijabarkan diatas maka akan dilakukan suatu penelitian dalam mengembangkan bahan ajar berupa e-modul dengan judul " Pengembangan E-Modul Berbasis Inkuiri Terbimbing Terintegrasi Multirepresentasi dan virtual laboratory Pada Materi Larutan Elektrolit dan Nonelektrolit SMA/ MA".

\section{Metode}

Jenis penelitian yang digunakan adalah penelitian dan pengembangan (Research and Development). Penelitian pengembangan adalah penelitian yang digunakan untuk menghasilkan produk tertentu dan menguji keefektivan produk tersebut [20] .Penelitian ini menggunakan model 4D. Adapun tahapan dalam model 4D adalah yaitu: (1) define (pendefinisian), (2) design (perancangan), (3) develop (pengembangan) dan (4) disseminate (penyebaran) [21]. Adapun uraian dari tahap tersebut adalah:

Pada tahap define terdapat 5 kegiatan utama yang harus dilakukan, yaitu (1) analisis ujung depan. Pada analisis ini peneliti menetapkan masalah dasar yang dihadapi siswa dan guru dalam pembelajaran. Pada analisis ujung depan, peneliti melakukan wawancara dengan tiga orang guru dari tiga sekolah yang berbeda yaitu SMAN 2 Pariaman, SMAN 4 Pariaman dan MAN Padusunan Kota Pariaman. (2) Analisis Siswa. Analisis ini bertujuan untuk mengidentifikasi target pembelajaran yaitu peserta didik. Informasi ini didapatkan melalui wawancara dengan guru. Pada tahapan analisis siswa, juga dilakukan wawancara dengan guru mata pelajaran kimia serta menyebarkan angket kepada siswa . Berdasarkan hasil wawancara yang dilakukan, model pembelajaran inkuiri terbimbing cocok diterapkan pada proses pembelajaran siswa SMA. Dengan mengetahui dan memahami karakteristik yang dimiliki peserta didik, maka akan memudahkan penulis dalam merancang bahan ajar yang sesuai dengan karakteristik peserta didik sehingga dihasilkan bahan ajar yang cocok digunakan oleh peserta didik. (3) Analisis tugas. Analisis ini bertujuan untuk mengidentifikasi dan menganalisis kemampuan yang harus dikuasai siswa melalui penentuan isi dalam satuan pembelajaran yang sesuai dengan kurikulum 2013.Ini dapat berupa analisis Kompetensi Dasar (KD) dan bahan materi pelajaran. Selanjutnya dilakukan perumusan indikator pencapaian kompetensi yang sesuai dengan KD (3.8), dan (4.8) untuk mengetahui kompetensi yang 
harus dicapai setelah pembelajaran. Berdasarkan indikator pencapaian kompetensi yang dirumuskan. (4) Analisis Konsep. Analisis ini dilakukan dengan cara mengidentifikasi seluruh konten yang terdapat dalam materi larutan elektrolit dan nonelektrolit. Hasil akhirnya akan dicantumkan dalam analisis konsep.(5) Analisis tujuan pembelajaran. Analisis tujuan pembelajaran merupakan tahap pengubahan hasil analisis tugas dan analisis konsep ke dalam tujuan pembelajaran. Analisis ini dijadikan dasar untuk mengkonstruksi bahan ajar dalam bentuk e-modul yang berbasisi inkuiri terbimbing terintegrasi multirepresentasi dan virtual laboratory yang disusun.

Tahap perancangan (design) bertujuan untuk merancang e-modul yang berbasisi inkuiri terbimbing terintegrasi multirepresentasi dan virtual laboratory berdasarkan Kompetensi Dasar (KD) dan bahan materi pelajaran sesuai kurikulum 2013. Tahapan perancangan meliputi: (1) Penyusunan tes. Pada penyusunan tes ini disajikan soal evalusi belajar, yang tujuannya dapat mengetahui kemampuan siswa setelah mempelajari materi tersebut. Ini disesuikan dengan kisi-kisi soalnya. (2) Pemilihan Media. Pemilihan media yang akan digunakan dalam pembeuatan e-modul. Media yang digunakan adalah media gambar, animasi, dan vidio. (3) Pemilihan format. Pemilihan format disesuikan dengan unsurunsur yang terdapat dalam modul yaitu : cover, kata pengantar, daftar isi, daftar gambar, daftar tabel, petunjuk belajar bagi guru dan peserta didik, kompetensi yang akan dicapai, lembar kegiatan dan lembar kerja, serta lembar evaluasi[22]. (4) Desain awal. Pada desain awal ini peneliti menetapkan judul dan identifikasi materi pokok, menentukan KI dan KD, menentukan IPK, merancang materi sesui tahapan inkuiri, membuat model eksplorasi berupa animasi dan vidio, membuat pertanyaan kritis sesui model yang disajikan, membuat latihan dan penutup merupakan aplikasi langsung dari konsep, merancang desain e-modul pada aplikasi Microsoft Word 2007 dan menyimpan dalam format PDF dan menjadikannya ke e-modul dengan memasukan format PDF ke dalam software e-modul, yaitu Kvisoft Flipbook Maker.

Tahap pengembangan (Develop). Pada tahap ini dilakukan penilaian terhadap e-modul yang dirancang. Terdapat 2 hal yang dinilai yaitu validitas e-modul dan praktikalitas e-modul. Validitas e-modul bertujuan untuk mengungkapkan validitas dari bahan ajar dalam bentuk e-modul berbasis inkuiri terbimbing yang dikembangkan. Dalam validitas ini disebarkan angket kepada para ahli . Ahli yang terlibat adalah 3 dosen kimia FMIPA UNP dan 2 orang guru SMAN 4Kota Pariaman . Apabila terdapat bagian pada e-modul yang dianggap kurang tepat oleh validator maka dilakukan revisi. Selanjutnya, dilakukan uji praktikalitas oleh siswa dan guru tujuannya untuk mengetahui tingkat kemudahan dalam penggunaan e-modul, efesiensi waktu dan manfaat dari e-modul yang dirancang.

Tahap penyebaran (disseminate).Pada konteks pengembangan bahan ajar e-modul tidak dilaksanakan, karena keterbatasan waktu dan biaya.

Instrumen yang digunakan adalah angket validitas dan angket praktikalitas. Data yang diperoleh dianalisis menggunakan formula momen Kappa cohen [23], sehingga akan diperoleh momen kappa.

Keterangan:

$$
\text { moment kappa }(k)=\frac{P-P e}{1-P e}
$$

$\mathrm{k}=$ moment kappa

$\mathrm{P}=$ Proporsi yang terealisasi (observed agreement)

$\mathrm{Pe}=$ Proporsi yang tidak terealisasi (expected agreement)

Tabel 1. Kategori keputusan berdasarkan moment kappa(k)

\begin{tabular}{c|c} 
Interval & Kategori \\
\hline $0,81-1,00$ & sangat tinggi \\
\hline $0,61-0,80$ & Tinggi \\
\hline $0,41-0,60$ & Sedang \\
\hline $0,21-0,40$ & Rendah \\
\hline $0,01-0,20$ & sangat rendah \\
\hline 0,00 & tidak valid
\end{tabular}




\section{Hasil dan Pembahasan}

\subsection{Tahap Define (Pendefinisian)}

3.1.1. Analisis ujung depan. Pada analisis ujung depan ini, peneliti melakukan wawancara dengan tiga orang guru dari tiga sekolah yang berbeda yaitu SMAN 2 Pariaman, SMAN 4 Pariaman dan MAN Padusunan Kota Pariaman. Berdasarkan hasil angket siswa yang dilakukan di tiga sekolah tersebut diperoleh informasi bahwa: 1) Buku cetak sebagai bahan ajar yang digunakan belum menuntun peserta didik untuk belajar mandiri (2) Bahan ajar yang digunakan belum menarik karena tidak disertai dengan gambar, vidio dan animasi (3) Kegiatan eksperimen/ praktikum yang dilakukan tidak terintegrasi dalam kegiatan pembelajaran tetapi dilakukan secara terpisah sehingga membutuhkan waktu yang lama dan ada juga sekolah tidak melakukan praktikum. Berdasarkan hasil wawancara guru, disimpulkan bahwa pembelajaran telah dilaksanakan sesui dengan kurikulum 2013. Salah satu tuntutan kurikulum 2013 adalah proses pembelajaran dengan pendekatan saintifik (5M) dan menggunakan model inkuiri terbimbing.

3.1.2. Analisis siswa. Pada tahapan analisis siswa ini, juga dilakukan wawancara dengan guru mata pelajaran kimia serta menyebarkan angket kepada siswa Berdasarkan hasil wawancara yang dilakukan, model pembelajaran inkuiri terbimbing cocok diterapkan pada proses pembelajaran siswa SMA. Dalam teori kognitif Piaget, usia SMA (15-17 tahun) termasuk kedalam tahap operasional formal. Pada tahap ini seseorang memiliki kemampuan untuk berfikir abstrak dan murni simbolis. Disamping itu, kemampuan seseorang untuk memecahkan masalah melalui kegiatan eksperimen sistematis juga telah terbentuk. Karakteristik siswa yang seperti ini dijadikan sebagai salah satu pertimbangan dalam mengembangakan e-modul berbasis inkuiri terbimbing terintegrasi multirepresentasi dan virtual laboratory.

3.1.3. Analisis Tugas . Pada tahapan analisis tugas, peneliti melakukan analisis terhadap kompetensi dasar (KD) berdasarkan kurikulum 2013 revisi 2013. Adapun Kompetensi Dasar yang dianalisis adalah sebagai berikut: 3.8 Menganalisis sifat larutan berdasrkan daya hantar listriknya. KD 4.8 tidak dilakukan karena e-modul yang dihasilkan terintegrasi virtual laboratory, dimana siswa tidak diperintahkan untuk melakukan praktikum.

3.1.4. Analisis Konsep. Pada analisis ini, peneliti melakukan identifikasi terhadap konsep-konsep penting yang akan dipelajari pada materi larutan elektrolit dan nonelektrolit. Adapun diantara konsep penting yang perlu dipahami oleh siswa pada materi laju reaksi ini adalah: pelarut, zat terlarut, larutan elektrolit, larutan nonelektrolit, elektrolit kuat, elektrolit lemah, nonelektrolit dan derajat ionisasi.

3.1.5. Analisis tujuan pembelajaran. Berdasarkan pada indikator pencapaian kompetensi yang telah ditentukan, maka dapat dijabarkan tujuan pembelajaran sebagai berikut: Melalui model Inkuiri Terbimbing peserta didik mampu menjelaskan sifat larutan berdasarkan daya hantar listriknya dan membedakan daya hantar listrik berbagai larutan melalui perancangan dan pelaksanaan percobaan serta mengembangkan nilai karakter berfikir kritis, kreatif ( kemandirian ),kerja sama ( gotong royong), mengkomonikasikan dan kejujuran,dengan mempelajari buku cetak, LKS, E-Modul maupun bahan ajar lainnya.

\subsection{Tahap Design (Perancangan)}

Ada tiga hal yang dilakukan oleh peneliti dalam tahapan design ini, yaitu penyusunan tes, pemilihan media, pemilihan format, dan rancangan awal. Proses perancangan e-modul berbasis inkuiri terbimbing terintegrasi multirepresentasi dan virtual laboratory pada materi larutan elektrolit dan nonelektrlit ini dilakuakn dengan menggunakan Microsoft word 2007 dirubah kedalam format PDF. Selanjutnya dirubah kedalam bentuk e-modul dengan menggunakan aplikasi Kvisoft Flipbook Maker. Bagianbagian penyusunan tersebut antara lain cover, petunjuk belajar, kompetensi yang akan dicapai, peta konsep, lembar kegiatan siswa, lembar kerja, lembar evaluasi,serta kunci jawaban[22] 


\subsection{Tahap Develop (Pengembangan)}

3.3.1. Uji Validitas. Uji validitas dari e-modul berbsasis inkuiri terbimbing terintegrasi multirepresentasi dan virtual laboratory dilakukan oleh lima orang validator, diantaranya adalah tiga orang dosen kimia FMIPA UNP dan dua orang guru kimia SMAN 4 Pariaman. Dalam menguji kevalidan suatu produk yang dihasilkan dapat digunakan pendapat para ahli minimal jumlahnya 3 orang [20]. Terdapat empat komponen yang dinilai oleh para ahli yang terlibat dalam pengujian validitas ini, yaitu komponen isi, komponen penyajian, komponen kebahasaan dan komponen kegrafisan [11]. Data yang diperoleh dari ke lima validator tersebut dilakukan analisis dengan menggunakan momen kappa $(\mathrm{k})$. Dalam analisis validitas isi, validitas konstruk serta praktikalitas dapat didasarkan kepada categorical judgements .

Perolehan rata-rata momen kappa pada komponen isi adalah 0,88 dengan tingkat kevalidan yang sangat tinggi. Nilai momen kappa tersebut menginformasikan bahwa e-modul larutan elektrolit dan nonelektrolit yang dihasilkan telah sesui dengan tuntutan kompetensi dasar yaitu Kompetensi Dasar 3.8. Modul yang baik dihasilkan apabila modul tersebut telah sesui dengan Kompetensi Dasar [23]. E-modul yang dihasilkan memuat kesesuain antara soal-soal yang diberikan dengan materi yang dipelajari. Tampilan animasi, vidio praktikum dan gambar memberikan informasi dan membantu siswa dalam memahami materi larutan elektrolit dan nonelektrolit. Hal ini sesui bahwa e-modul yang baik dilengkapi dengan penyajian vidio tutorial, animasi dan audio untuk memperkaya pengalaman belajar siswa[17].

Perolehan rata-rata momen kappa pada komponen kebahasaan adalah 0,86 dengan kategori kevalidan sangat tinggi. Hal ini menunjukkan bahwa bahasa yang digunakan dalam e-modul telah sesui dengan kaidah bahasa Indonesia sehingga informasi yang diberikan mudah dipahami siswa dan tidak menimbulkan kerancuan. Bentuk dan ukuran huruf jelas terbaca karena bentuk huruf yang digunakan adalah Times New Roman dan ukuran huruf 16,18,20,24. Penggunaan simbol yang terdapat pada e-modul sudah konsisten. Bahan ajar yang baik apabila dilakukan evaluasi terhadap komponenkomponen didalamnya yakni keterbacaan, kejelasan informaso, kesesuaian kaidah Bahasa Indonesia yang baik dan benar serta penggunaan bahasa yang jelas dan mudah dipahami [11].

Perolehan rata-rata momen kappa pada komponen penyajian adalah 0,91 dengan tingkat kevalidan yang sangat tinggi. Ini menginformasikan bahwa e- modul larutan elektrolit dan nonelektrolit yang dihasilkan telah tersusun secara sistematis dengan unsur-unsur modul pembelajaran [22]. Selain itu e-modul yang dihasilkan sudah memuat aspek komponen penyajian sesui dengan tahapan inkuiri terbimbing yaitu tahap orientasi, eksplorasi dan pembentukan konsep, aplikasi dan penutup [10]

Perolehan rata-rata momen kappa pada komponen kegrafisan adalah 0,92 dengan tingkat kevalidan yang sangat tinggi. Ini menginformasikan bahwa e-modul larutan elektrolit dan nonelektrolit yang dihasilkan memiliki tulisan yang dapat dibaca dengan jelas, memiliki layout atau tampilan cover antar bagian dalam e-modul menarik serta gambar, animasi dan vidio yang ditampilkan teramati dengan jelas.

Dari kelima validator didapatkan rata-rata kevalidan bahan ajar e-modul berbasis inkuiri terbimbing terintegrasi multirepesentasi dan virtual laboratory pada materi larutan elektrolit dan nonelektrolit 0.90 dengan tingkat kevalidan sangat tinggi. Hasil pengolahan data penilaian angket validitas e-modul berbasis inkuiri terbimbing terintegrasi multirepresentasi dan virtual laboratory pada materi larutan elektrolit dan nonelektrolit. untuk setiap komponen dapat dilihat pada Grafik 1. 


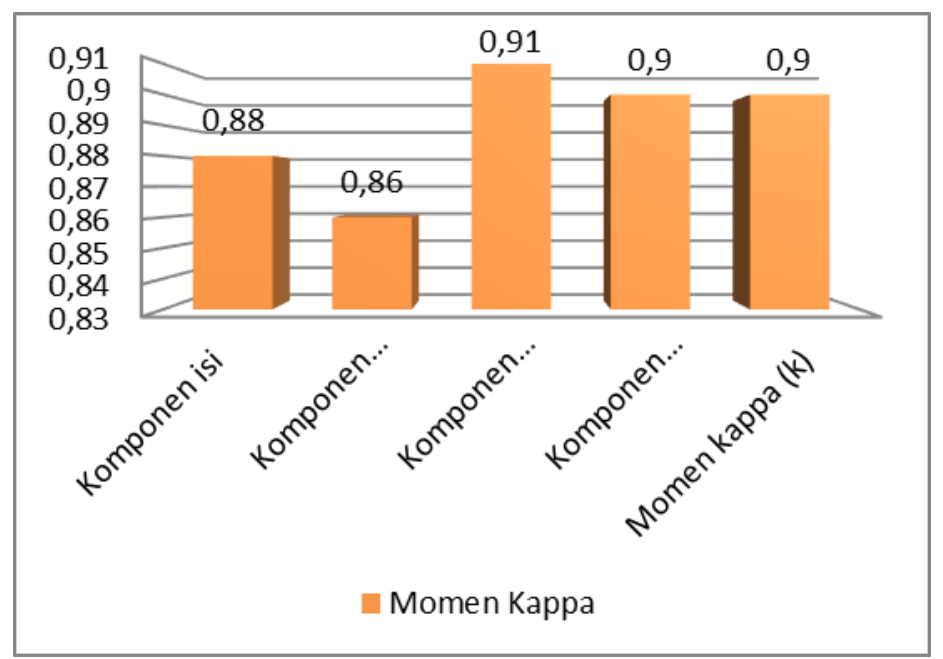

Grafik 1. Nilai momen kappa uji validitas dari empat komponen yang dinilai.

3.3.2. Uji Praktikalitas. Praktikalitas e-modul larutan elektrolit dan nonelektrolit berbasis inkuiri terbimbing terintegrasi multirepresentasi dan virtual laboratory dilakukan oleh 2orang guru kimia SMAN 4 dan 25 siswa kelas X SMAN 4 Pariaman. Suatu bahan ajar dikatakan praktis jika bahan ajar tersebut dapat dengan mudah digunakan dalam pembelajaran [24]. Praktikalitas yang dinilai terdiri dari 3 komponen yaitu kemudahan penggunaan, efesiensi waktu belajar dan manfaat.

Kemudahan penggunaan e-modul dari guru memiliki rata-rata momen kappa sebesar 0,97 dengan kategori sangat tinggi kepraktisan dan dari siswa 0,87 dengan kategori sangat tinggi kepraktisan. Hal ini telah menunjukkan bahwa e-modul yang dikembangkan telah memiliki petunjuk penggunaan yang mudah dipahami. Materi yang disajikan jelas dan sederhana serta secara keseluruhan isi e-modul yang dikembangkan dapat dipahami oleh guru dan siswa. E-modul mudah digunakan /dioperasikan, digunakan berualng-ulang serta e-modul mudah untuk dibawa karena dapat disimpan dalam falsdisk sehingga dapat diakses dengan komputer/ laptop dimana saja. Pengoperasikan modul elektronik sangat mudah, unsur musik dan animasi dinilai dapat meningkatkan motivasi, minat dan aktivitas belajar siswa [15].

Efesiensi waktu pembelajaran e-modul memiliki rata-rata momen kappa sebesar 1,00 dengan kategori sangat tinggi kepraktisan dan dari siswa 0,80 dengan kategori tinggi kepraktisan. Dalam penggunaan modul dapat membuat waktu pembelajaran menjadi efisien dan siswa belajar sesuai dengan kecepatan belajar masing-masing [25]. Ini sangat membantu siswa dalam mempelajari materi larutan elektrolit dan nonelektrilit dimana pada e-modul disajikan model berupa animasi submikroskopis, gambar dan vidio praktikum.

Aspek manfaat e-modul memiliki rata-rata momen kappa sebesar 0,98 dengan kategori sangat tinggi kepraktisan dan dari siswa 0,83 dengan kategori sangat tinggi kepraktisan. E-modul yang dikembangkan dapat membantu siswa belajar mandiri dan dapat memahami materi melalui vidio, animasi, gambar atau melalui pertanyaan-pertanyaan yang disajikan dlam e-modul sehingga dapat meningkatkan semangat siswa dalam belajar. Bahwa modul yang dikemas dalam elektronik memungkinkan siswa belajar secara mandiri[15]. E-modul dapat mendukung peran guru sebagai fasilitator karena langkah-alangkah yang disajikan dalam e-modul jelas, sistematis dan mudah dipahami siswa. Oleh karena itu guru tidak perlu menjelaskan materi terlalu banyak karena siswa harus lebih berperan aktif dalam proses pembelajaran sehingga pembelajaran tidak berpusat pada guru (teacher center).

Dari penilaian praktikalitas oleh guru diperoleh rata-rata momen kappa sebesar 0,98 dengan kategori kepraktisan sangat tinggi dan oleh siswa sebesar 0,83 dengan kategori kepraktisan sangat tinggi. Hasil pengolahan data penilaian angket praktikalitas guru dan siswa terhadap e-modul berbasis inkuiri terbimbing terintegrasi multirepresentasi dan virtual laboratory pada larutan elektrolit dan nonelektrolit untuk setiap komponen dapat dilihat pada Grafik 2. 


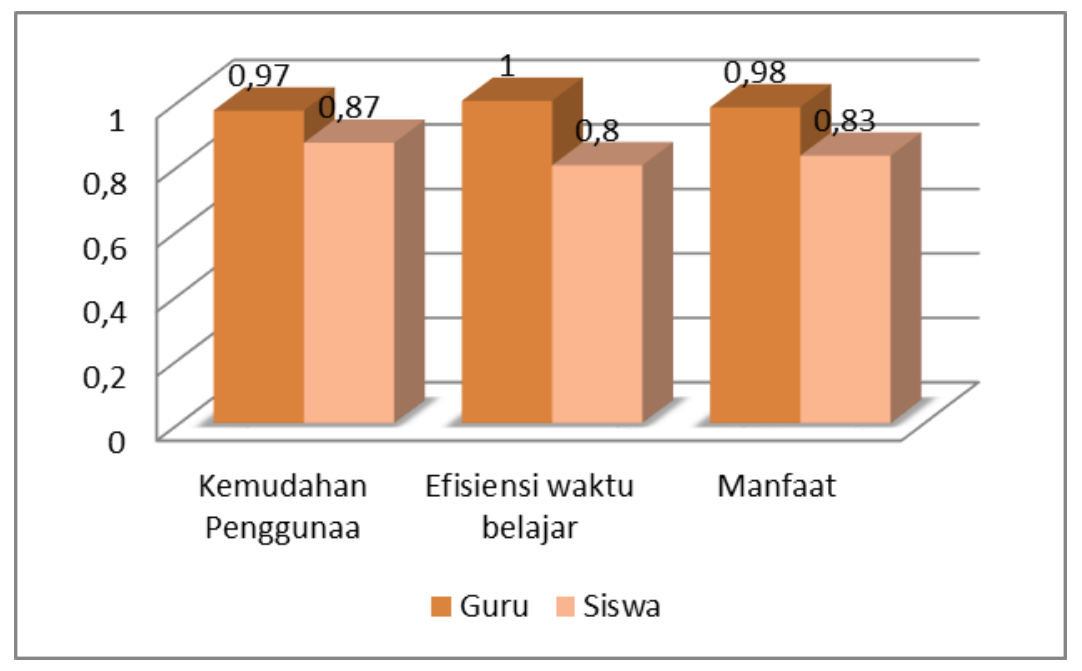

Grafik 2. Nilai momen kappa uji praktikalitas pada tiga komponen yang dinilai oleh siswa dan guru.

\section{Kesimpulan}

Berdasarkan Penelitian yang telah dilakukan, dapat disimpulan bahwa e-modul berbasis inkuiri terbimbing terintegrasi multirepresentasi dan virtual laboratory pada materi larutan elektrolit dan nonelektrolit untuk kelas X SMA / MA menggunakan model 4D. Diketahui juga bahwa e-modul berbasis inkuiri terbimbing terintegrasi multirepresentasi dan virtual laboratory pada materi larutan elektrolit dan nonelektrolit untuk kelas X SMA / MA yang dihasilkan mempunyai tingkat kevalidan dan kepraktisan yang sangat tinggi.

\section{Referensi}

[1] Chang, R. 2008. General Chemistry: The Essential Concept Fifth Edition. New York: Mc Graw Hill Higher Education

[2] Permendiknas No 59 tahun 2014, tentang standar isi

[3] Tawil,muh \& Liliasari. 2014. Keterampilan-Keterampilan Sains dan Implementasinya dalam Pembelajaran IPA. Makasar : UNM

[4] Andromeda,dkk, 2018. Validitas dan Praktikalitas Modul Laju Reaksi Terintegrasi Eksperimen dan Keterampilan Proses Sains untuk Pembelajaran Kimia di SMA . Jurnal Eksata Pendidikan, Volume 2 November 2018 ISSN 2614-1221

[5] Andromeda,dkk.2019. Effectiveness of chemical equilibrium module based guided inquiry integrated experiments on science process skills high school students. Journal of physics. Conf. Serie1s116(2018) 042007

[6] Hendra, Jaya. (2012). Virtual Laboratory Development For Practicum And Facilitating Character Education In Vocational High School. Jurnal Pendidikan Vokasi, Vol 2, Nomor 1, Februari 2012 .

[7] Fauziah, R. 2013. Pembelajaran Saintifik Ektronik Dasar Berorientasi Pembelajaran Berbasis Masalah. Jurnal INVOTEC, Volume IX, no. 2, Agustus 2011

[8] Winda, M. (2014). Peningkatan Keaktifan Siswa Melalui Penerapan Metode Discovery dalam Pembelajaran Pkn di Kelas X SMA Negeri 2Lengayang Pesisir Selatan. TINGK

[9] Suyanti, R.W. 2010. Strategi Pembelajaran Kimia. Yogyakarta. Graha Ilmu

[10] Abidin, Y. 2014. Desain Sistem Pembelajaran dalam Konteks Kurikulum 2013. Bandung: Refika Aditama.

[11] Departemen Pendidikan Nasional. 2008. Pengembangan Bahan Ajar. Jakarta: Departemen Pendidikan Nasional, Direktorat Jenderal Manajemen Pendidikan Dasar dan Menengah

[12] Wiyoko, Sarwanto, Dwi Teguh Rahardjo. 2014. Penembangan media pembelajaran fisika modul 
elektronik animasi interaktif untuk Kelas XI SMA Ditinjau Dari Motivasi Belajar Siswa. Jurnal Pendidikan Fisika Vol.2 No.2 hal 11.

[13] Nasution, S. 2011. I Berebagai Pendekatan dalam Proses Belajar dan Mengajar. Jakarta: Bumi Aksara

[14] Roestiyah. 2008. Strategi Belajar Mengajar. Jakarta : Rineka Cipta

[15] Wijayanto, M. S. (2014). Pengembangan E-Modul Berbasis Flip Book Maker Dengan Model Project based learning Untuk Mengembangkan Kemampuan Pemecahan Masalah Matematika. Prosiding Mathematics and Sciences Forum, 625-628.

[16] Suasarna dan Mahayukti. 2013. Pengembangan e-modul berorientasi pemecahan masalah untuk meningkatkan keterampilan berpikir Kritis mahasiswa . jurnal Pendidikan Indonesia Vol 2 No. 2, 264-275.

[17] Kemendikbud. 2017. Panduan implementasi kecakapan abad 21 kurikulum 2013 di sekolah menegah atas. Jakarta : Ditjen Pensisiakn Dasar dan Menegah

[18] Maida, Claudy Margarita, Bayharti, Andromeda. 2019. Pengaruh Penggunaan Lembar Kerja Siswa (LKS) Eksperimen Laju Reaksi Berbasis Inkuiri Terbimbing Terhadap Hasil Belajar Siswa Kelas XI MIA SMAN 4 Padang. Jurnal Eksakta Pendidikan (JEP), Vol 3 No.1,75-81.

[19] Yerimadesi, Bayharti, Azizah, Lufri, Andromeda, Guspatni. 2019. Effectiveness of Acid-Base Modules Based on Guided Discovery Learning for Increasing Critical Thinking Skill and Learning Outcomes of Senior High School Student. IOP Conf. Ser: Journal of Physics. Conf. Series 118(2019)01215.

[20] Sugiyono. 2006. Metode Penelitian Pendidikan. Bandung: Alfabeta.

[21] Trianto. 2010. Model Pembelajaran Terpadu. Jakarta: Bumi Aksara.

[22] Suryosubroto, B. 1983. Sistem Pengajaran Dengan Modul.Yogyakarta : PT Bina Aksara.

[23] Boslaugh, Sand Andrew PW. 2008. Statistics in a Nutshell, a Desktop Quick Reference. Beijing, Cambridge, Famham, Koin, Sebastopol, Taipei, Tokyo: O'reilly

[24] Mudjijo. 1999. Tes Hasil Belajar. Jakarta : Bumi Aksara

[25] Daryanto. 2014. Pendekatan Pembelajaran Saintifik Kurikulum 2013. Yogyakarta: PT Gavi Media. 